\title{
Synthesis and Decomposition of a Novel Carboxylate Precursor to Indium Oxide
}

Aloysius F. Hepp and Maria T. Andras

Lewis Research Center

Cleveland, Ohio

Stan A. Duraj

Cleveland State University

Cleveland, Ohio

Eric B. Clark

Lewis Research Center

Cleveland, Ohio

David G. Hehemann

Kent State University

Kent, Ohio

Daniel A. Scheiman

Sverdrup Technology, Inc.

Brook Park, Ohio

Phillip E. Fanwick

Purdue University

West Lafayette, Indiana

Prepared for the

Fall Meeting

sponsored by the Materials Research Society

Boston, Massachusetts, November 29-December 3, 1993

National Aeronautics and

Space Administration 


\title{
SYNTHESIS AND DECOMPOSITION OF A NOVEL CARBOXYLATE PRECURSOR TO INDIUM OXIDE
}

\author{
ALOYSIUS F. HEPP, ${ }^{*}$ MARIA T. ANDRAS, ${ }^{*}$, STAN A. DURAJ, ${ }^{* *}$ ERIC B. CLARK, \\ DAVID G. HEHEMANN, ${ }^{* * *}, \neq \ddagger$ DANIEL A. SCHEIMAN, ${ }^{\dagger}$ AND PHILLIP E. FANWICK ${ }^{\dagger \dagger}$ \\ *NASA Lewis Research Center, Photovoltaic Branch, M.S. 302-1, Cleveland, OH 44135 \\ ${ }^{* *}$ Department of Chemistry, Cleveland State University, Cleveland, $\mathrm{OH}, 44115$ \\ *** School of Technology, Kent State University, Kent, OH 44242 \\ tSverdrup Technology, Inc., 2001 Aerospace Parkway, Brook Park, OH 44142 \\ ††Department of Chemistry, Purdue University, West Lafayette, IN 47907
}

\section{ABSTRACT}

Reaction of metallic indium with benzoyl peroxide in 4-methylpyridine (4-Mepy) at $25^{\circ} \mathrm{C}$ produces an eight-coordinate mononuclear indium(III) benzoate, $\operatorname{In}\left(\eta^{2}-\mathrm{O}_{2} \mathrm{CC}_{6} \mathrm{H}_{5}\right)_{3}$ (4Mepy) $2 \cdot 4 \mathrm{H}_{2} \mathrm{O}$ (I), in yields of up to $60 \%$. The indium(III) benzoate was fully characterized by elemental analysis, spectroscopy, and X-ray crystallography; (I) exists in the crystalline state as discrete eight-coordinate molecules; the coordination sphere around the central indium atom is best described as pseudo-square pyramidal. Thermogravimetric analysis of (I) and X-ray diffraction powder studies on the resulting pyrolysate demonstrate that this new benzoate is an inorganic precursor to indium oxide. Decomposition of (I) occurs first by loss of 4-methylpyridine ligands $\left(100^{\circ}-200^{\circ} \mathrm{C}\right)$, then loss of benzoates with formation of $\mathrm{In}_{2} \mathrm{O}_{3}$ at $450^{\circ} \mathrm{C}$. We discuss both use of carboxylates as precursors and our approach to their preparation.

\section{INTRODUCTION}

Our interest in oxygen-containing gallium and indium complexes derives from efforts to produce precursors for deposition of thin-film materials for solar cell fabrication [1]. Oxides are deposited or grown on solar cells to provide electrical insulation, to decrease surface recombination, or to produce anti-reflective coatings [2]. A major issue surrounding technological applications of InP is the deposition of insulators on the surface that are chemically stable with good electrical and interfacial properties. With this goal in mind, we are searching for easy to prepare and handle chemical vapor deposition (CVD) precursors to $\mathrm{In}_{2} \mathrm{O}_{3}$. Recently, we reported the preparation and characterization of the first main group oxo-centered trimeric carboxylate, $\left[\mathrm{Ga}_{3}\left(\mu_{3}-\mathrm{O}\right)\left(\mu-\mathrm{O}_{2} \mathrm{CC}_{6} \mathrm{H}_{5}\right)_{6}(4-\mathrm{Mepy})_{3}\right]\left[\mathrm{GaCl}_{4}\right]$ [3]. In an attempt to prepare a monomeric indium benzoate, we reacted indium metal with benzoyl peroxide in 4-methylpyridine at $25^{\circ} \mathrm{C}$ and obtained In $\left(\eta^{2}-\mathrm{O}_{2} \mathrm{CC}_{6} \mathrm{H}_{5}\right)_{3}$ (4-Mepy) 2 (4-Mepy = 4-methylpyridine) (I) in good yields.

The existence of indium and gallium carboxylates is well-documented [4,5]. Numerous homoleptic polynuclear indium(III) carboxylates, $\left[\mathrm{In}\left(\mathrm{O}_{2} \mathrm{CR}\right)_{3}\right]_{x}\left(\mathrm{R}=\mathrm{H}, \mathrm{CH}_{3}, \mathrm{C}_{2} \mathrm{H}_{5}, n-\mathrm{C}_{3} \mathrm{H}_{7}\right.$, $\left(\mathrm{CH}_{3}\right)_{2} \mathrm{CH}$, and $\left(\mathrm{CH}_{3}\right)_{3} \mathrm{C}$ ) [6], as well as polynuclear organoindium(III) carboxylates, $\left[\mathrm{R}_{2} \operatorname{In}\left(\mathrm{O}_{2} \mathrm{CR}^{\prime}\right)\right]_{x}\left(\mathrm{R}=\mathrm{CH}_{3}, \mathrm{C}_{2} \mathrm{H}_{5}, \mathrm{R}^{\prime}=\mathrm{CH}_{3}, \mathrm{C}_{2} \mathrm{H}_{5}\right.$ or $\left.\mathrm{R}=n-\mathrm{C}_{4} \mathrm{H}_{9}, \mathrm{R}^{\prime}=\mathrm{C}_{2} \mathrm{H}_{5}\right)$ are known [610]; however, there is a void in the literature on analogous indium(III) benzoates. To the best of our knowledge, $\mathrm{Cl}_{2} \mathrm{In}\left(\eta^{2}-\mathrm{O}_{2} \mathrm{CC}_{6} \mathrm{H}_{5}\right)$ py 2 (py = pyridine), a six-coordinate mononuclear species, is the only structurally characterized indium(III) benzoato complex to date [11]. We describe the synthesis, structure and mass spectral analysis of the eight-coordinate mononuclear indium(III) benzoato complex (I). Thermogravimetric analysis (TGA) of (I) and X-ray diffraction powder (XRD) studies on the resulting pyrolysate demonstrate that this new benzoate is a precursor to indium (III) oxide, $\mathrm{In}_{2} \mathrm{O}_{3}$.

¥ - National Research Council/NASA Lewis Research Center Resident Research Associate. ¥ - Senior Research Fellow/NASA Lewis Research Center Resident Research Associate. 


\section{EXPERIMENTAL}

All operations of moisture- and air-sensitive materials were performed under an inert atmosphere using standard Schlenk techniques and a double-manifold vacuum line. Solids were manipulated in a Vacuum Atmospheres Co. drybox equipped with a HE-493 dri-train. Solvents were freshly distilled from sodium benzophenone ketyl prior to use. Solutions were transferred via stainless steel cannulae and/or syringes. Indium powder (Aldrich) was used without additional purification. Benzoyl peroxide was deareated under vacuum at room temperature. Elemental analyses were performed by Galbraith Microanalytical Laboratories, Inc. (Knoxville, TN). Thermogravimetric analyses were performed under an atmosphere of nitrogen using a Perkin Elmer TGS-II. Powder X-ray diffraction (XRD) data was collected using monochromated $\mathrm{Cu} \mathrm{K}_{\alpha}$ radiation on a Scintag PAD V and a Phillips APD diffractometer. Electron impact mass spectra were recorded on a Finnigan TSQ -45 mass spectrometer. X-ray diffraction data were collected at $20 \pm 1{ }^{\circ} \mathrm{C}$ on a $0.38 \times 0.38 \times 0.31 \mathrm{~mm}$ crystal using an Enraf-Nonius CAD -4 diffractometer.

$\mathrm{In}\left(\eta^{2}-\mathrm{O}_{2} \mathrm{CC}_{6} \mathrm{H}_{5}\right)_{3}$ (4-Mepy) 2 was prepared by reaction of 150 -mesh indium powder $(0.50 \mathrm{~g}$, $4.35 \mathrm{mmol})$ and benzoyl peroxide $(1.58 \mathrm{~g}, 6.52 \mathrm{mmol})$ in $35 \mathrm{~mL}$ of 4-methylpyridine at ambient temperature for several days. The mixture was filtered, and the resulting off-white solid washed with three $25 \mathrm{~mL}$ aliquots of hexane and dried under vacuum for $2 \mathrm{~h}$. Hexane, $150 \mathrm{~mL}$, was added to the bright yellow filtrate to further precipitate the white solid. The supernatant was decanted, and the white solid was washed with two $25 \mathrm{~mL}$ aliquots of fresh hexane and dried under vacuum for $2 \mathrm{~h}$. The solids were combined, recrystallized from 4-methylpyridine/hexane $(\mathrm{v} / \mathrm{v} 40 / 70)$ and dried under vacuum for $18 \mathrm{~h}$, the yield is $53-60 \%$. The analytical data was consistant with the single crystal X-ray structure and is detailed in a prior publication [12].

\section{RESULTS AND DISCUSSION}

Oxidation of indium metal by benzoyl peroxide in 4-methylpyridine produces the first mononuclear indium(III) benzoate in yields of up to $60 \%$ (Eq. 1):

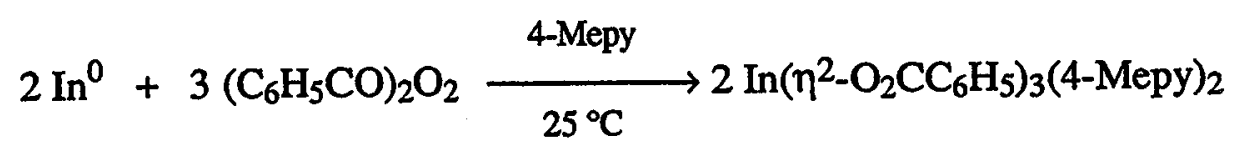

In $\left(\eta^{2}-\mathrm{O}_{2} \mathrm{CC}_{6} \mathrm{H}_{5}\right)_{3}$ (4-Mepy) 2 is very stable; it can be stored under an inert atmosphere at room temperature for extended periods of time. TGA studies show that it is thermally stable up to 100 ${ }^{\circ} \mathrm{C}$, at this temperature loss of 4-methylpyridine occurs. In contrast, pyridine adducts of indium(III) acetate and formate are unstable, losing pyridine slowly at room temperature [13].

Colorless single crystals, suitable for X-ray diffraction studies, were grown by slow interdiffusion of hexane into a 4-methylpyridine solution of $(\mathbf{I})$, the compound crystallized as the tetrahydrate $(\mathbf{I}) \cdot 4 \mathrm{H}_{2} \mathrm{O}$, no doubt from trace amounts of water in the coordinating solvent. Crystallographic data are summarized in Table 1 , a detailed description of the structural analysis is given in [12]. Single crystal X-ray diffraction analysis reveals that $(\mathrm{I}) \cdot 4 \mathrm{H}_{2} \mathrm{O}$ is composed of an ordered array of discrete mononuclear eight-coordinate molecules positioned on a crystallographic two-fold rotation axis. The solid-state molecular structure of (I) is shown in Figure 1 . The immediate coordination sphere around the central indium(III) atom is best described as a pseudosquare pyramid with each bidentate benzoate assuming a single position. The In atom is bound to six oxygen atoms from three equivalent (vide infra) bidentate benzoate groups. The In-O bond distances range from $2.225(6)$ to $2.413(5) \AA$. Within the symmetrically independent benzoato ligand, the In-O bond lengths are not equivalent. The In-O(22) bond length, 2.413(5) $\AA$, is slightly longer (by $0.19 \AA$ ) than the In-O(21) bond length, $2.225(6) \AA$. Unsymmetrical bonding of chelating carboxylate groups to an indium(III) center is not unusual [14]. 
TABLE 1.

Crystallographic Data for $\operatorname{In}\left(\eta^{2}-\mathrm{O}_{2} \mathrm{CC}_{6} \mathrm{H}_{5}\right)_{3}(4-\mathrm{Mepy})_{2} \cdot 4 \mathrm{H}_{2} \mathrm{O}$.

$\begin{array}{ll}\text { chemical formula } \mathrm{InO}_{10} \mathrm{~N}_{2} \mathrm{C}_{33} \mathrm{H}_{37} & \text { formula weight } 736.49 \\ a=11.7195(8) \AA & \text { space group C2/c (No. 15) } \\ b=11.995(1) \AA & \mathrm{T}=20^{\circ} \mathrm{C} \\ c=25.407(2) \AA & \lambda=0.71073 \AA \\ \beta=94.177(6)^{\circ} & \rho_{\text {calc }}=1.373 \mathrm{~g} \mathrm{~cm}^{-3} \\ V=3562.0(8) \AA^{3} & \mu\left(\mathrm{Mo} \mathrm{K \alpha}=7.04 \mathrm{~cm}^{-1}\right. \\ \mathrm{Z}=4 & \mathrm{R}_{\left(\mathrm{F}_{\mathrm{O}}\right)^{\mathrm{a}}=0.059} \\ & \mathrm{R}_{w}\left(\mathrm{~F}_{0}\right)^{\mathrm{b}}=0.079\end{array}$

a $R\left(F_{0}\right)=\Sigma\left\|F_{o} l-\left.\left|F_{c} \| / \Sigma\right| F_{o}\left|;{ }^{b} R_{w}\left(F_{0}\right)=\left[\Sigma w\left|F_{0}\right|-\left|F_{c}\right|\right]^{2} / \Sigma w\right| F_{0}\right|^{2}\right]^{1 / 2} ; w=1 / \sigma^{2}\left(\left|F_{0}\right|\right)$.
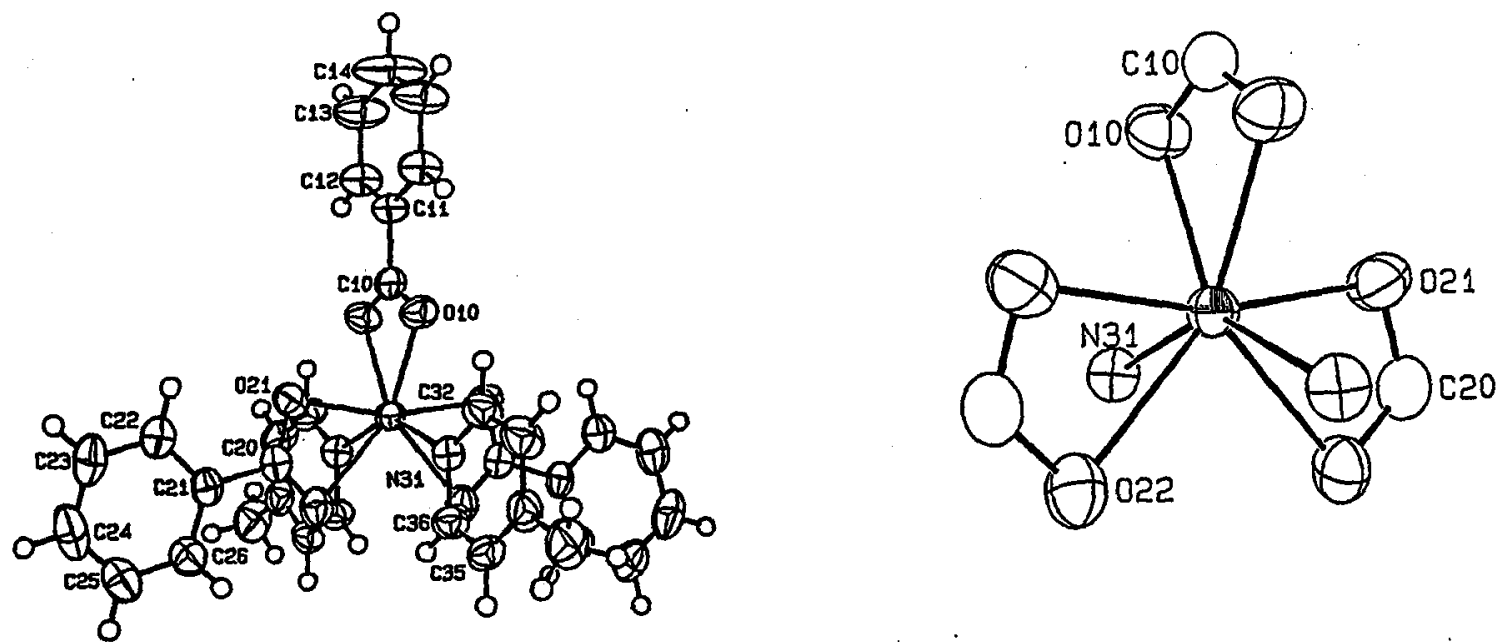

Figure 1. ORTEP drawing of the $\operatorname{In}\left(\eta^{2}-\mathrm{O}_{2} \mathrm{CC}_{6} \mathrm{H}_{5}\right)_{3}(4-\mathrm{Mepy})_{2}$ molecule showing $50 \%$ thermal ellipsoids and the atomic labeling scheme. Compound (1) $\mathrm{InO}_{6} \mathrm{~N}_{2}$ core on right.

A common reactivity/bonding characteristic of indium(III) complexes is the expansion of the indium(III) atom coordination sphere through polymerization or adduct formation [6-15]. In the case of indium(III) carboxylates (of which (I) is an example), the coordination number of the indium(III) atom generally increases to 6 or 8 via polymerization of the [In(OOCR) 3 ] units oxygen atoms from adjacent carboxylate molecules bridge the units creating infinite [In(OOCR $\left.)_{3}\right]_{n}$ chains. In (I), the presence of the two methylpyridine ligands prevents such polymerization by coordinatively saturating the indium(III) atom, resulting in the formation of the first mononuclear eight-coordinate indium(III) benzoato species. The tendency to associate can be seen by the complete lack of parent ions in mass spectra with 25 and $70 \mathrm{eV}$ ionization. The most intense peaks in the spectra, with m/e values: 105 and 77 , correspond to loss of $\mathrm{O}$ and $\mathrm{CO}_{2}$ from the benzoate group to form $\mathrm{C}_{6} \mathrm{H}_{5}+$ and $\mathrm{C}_{6} \mathrm{H}_{5}(\mathrm{CO})^{+}$ions. While much less intense, the strongest metal-containing ion peaks, in decending intensity order are m/e (for $115 \mathrm{In}): 357,313,115,269$, 435,479 , these peaks can be assigned to, respectively: $\mathrm{In}\left(\mathrm{O}_{2} \mathrm{CC}_{6} \mathrm{H}_{5}\right)_{2}+, \mathrm{C}_{6} \mathrm{H}_{5} \mathrm{In}\left(\mathrm{O}_{2} \mathrm{CC}_{6} \mathrm{H}_{5}\right)^{+}$, $\mathrm{In}^{+},\left(\mathrm{C}_{6} \mathrm{H}_{5}\right)_{2} \mathrm{In}^{+},\left(\mathrm{C}_{6} \mathrm{H}_{5}\right) \mathrm{In}\left(\mathrm{O}_{2} \mathrm{CC}_{6} \mathrm{H}_{5}\right)_{2}{ }^{+}$, and $\mathrm{In}\left(\mathrm{O}_{2} \mathrm{CC}_{6} \mathrm{H}_{5}\right)_{3}+$. While the volatility of (I) is low at decomposition, the compound readily produces $\mathrm{In}_{2} \mathrm{O}_{3}$. 
Thermal decomposition of $\operatorname{In}\left(\eta^{2}-\mathrm{O}_{2} \mathrm{CC}_{6} \mathrm{H}_{5}\right)_{3}(4-\mathrm{Mepy})_{2}$ was followed by TGA in both air and nitrogen, and the composition of the final pyrolysate determined by XRD. No attempt was made to identify the intermediate pyrolysates produced during this analysis. The first two steps in the thermogram (see Figure 2) correspond to the sequential loss of the two 4-methylpyridine ligands. The same results were obtained in air and nitrogen. This lack of effect on the formation of oxide is expected due to the In $\mathrm{O}_{6} \mathrm{~N}_{2}$ coordination environment around indium, it is also consistant with the ready decomposition of benzoate seen in the mass spectra.

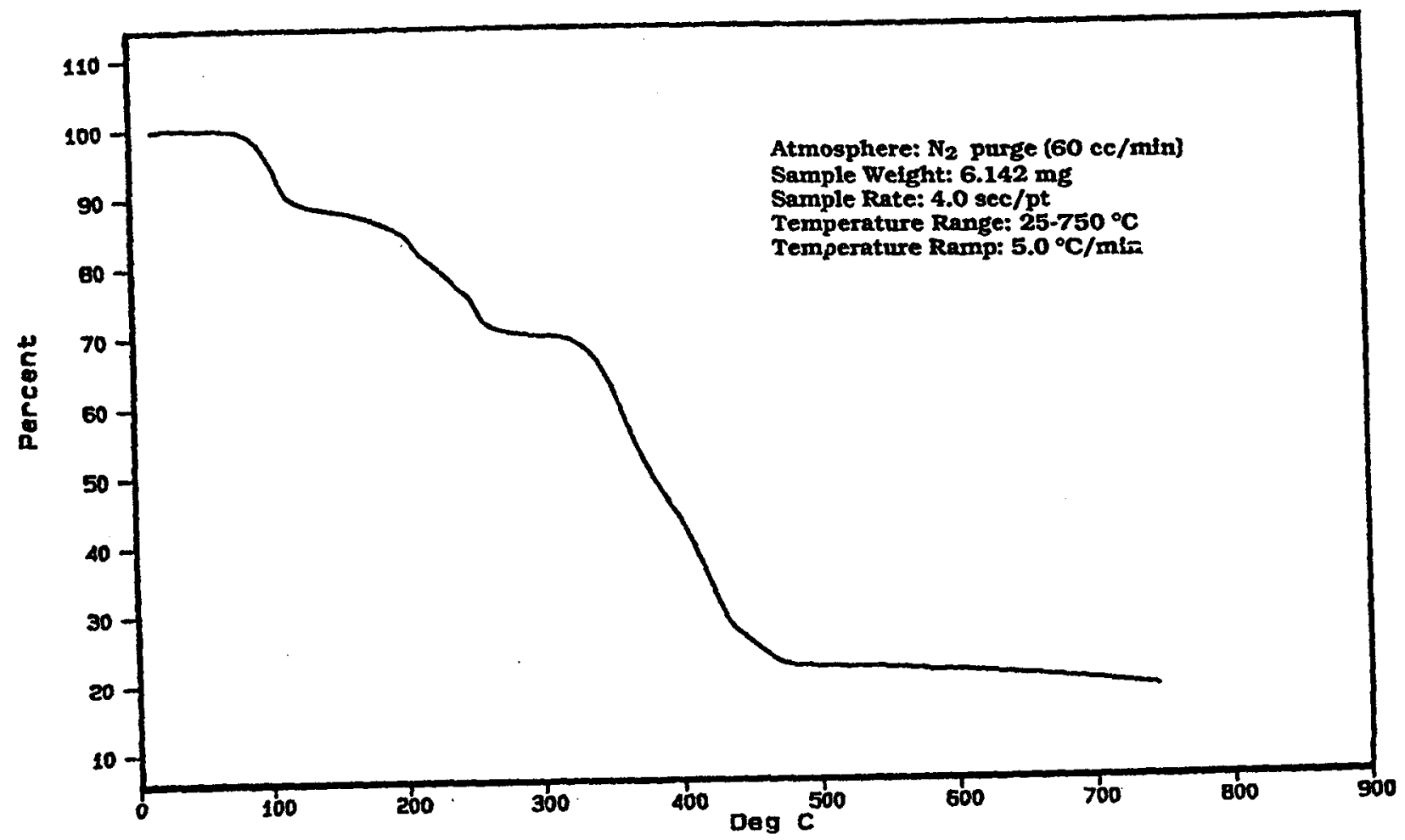

Figure 2. Thermogravimetric analysis of $\mathrm{In}\left(\eta^{2}-\mathrm{O}_{2} \mathrm{CC}_{6} \mathrm{H}_{5}\right)_{3}(4-\mathrm{Mepy})_{2}$ under an atmosphere of nitrogen. The theoretical values for weight changes are: $86 \%$, $\ln \left(\mathrm{O}_{2} \mathrm{CC}_{6} \mathrm{H}_{5}\right)_{3}(4-\mathrm{Mepy})_{2}$ - (4Mepy)]; 72\%, [n( $\left.\left(\mathrm{O}_{2} \mathrm{CC}_{6} \mathrm{H}_{5}\right)_{3}(4-\mathrm{Mepy})_{2}-2(4-\mathrm{Mepy})\right] ; 21 \%, \operatorname{In} 2 \mathrm{O}_{3} / \mathrm{In}\left(\mathrm{O}_{2} \mathrm{CC}_{6} \mathrm{H}_{5}\right)_{3}(4-\mathrm{Mepy})_{2}$.

The final weight loss corresponds to complete decomposition of $\operatorname{In}\left(\eta^{2}-\mathrm{O}_{2} \mathrm{CC}_{6} \mathrm{H}_{5}\right)_{3}(4-\mathrm{Mepy})_{2}$ to $\mathrm{In}_{2} \mathrm{O}_{3}$, as demonistrated by weight loss and XRD pattern, Table $2[16,17]$. The most interesting aspect of the TGA data is the relatively low temperature $\left(475^{\circ} \mathrm{C}\right)$ for the stabilization of weight loss. By contrast, the polymeric $\operatorname{In}\left(\eta^{2}-\mathrm{O}_{2} \mathrm{CCH}_{3}\right)_{n}$ [13], did not reach a stable mass until between 1000 and $1100^{\circ} \mathrm{C}$, above the sublimation temperature of $\operatorname{In}_{2} \mathrm{O}_{3}$ of $850^{\circ} \mathrm{C}$ [18]. No attempt was made to characterize the intermediate materials. The morphology of material produced during a typical thermal analysis run is shown in a scanning electron micrograph, figure 3 . As can be seen, melting has occurred in the material, as the temperature of the sample reached $750^{\circ} \mathrm{C}$; this is still $300^{\circ} \mathrm{C}$ below the temperature needed to fully convert the polymeric acetate [13]. 


\section{TABLE 2.}

$\mathrm{X}$-ray Diffraction (XRD) Powder Pattern for Pyrolysate, $\mathrm{In}_{2} \mathrm{O}_{3}$, Between 1.20 and $5.00 \AA$.

\begin{tabular}{clr} 
Angle, 20 & d, $\AA$ & I/Imax, \% \\
\hline 21.522 & 4.126 & 1.18 \\
30.750 & 2.905 & 100.00 \\
35.510 & 2.53 & 35.19 \\
37.725 & 2.383 & 3.48 \\
41.895 & 2.155 & 11.72 \\
45.710 & 1.983 & 6.64 \\
49.302 & 1.847 & 3.11 \\
51.115 & 1.786 & 65.64 \\
52.745 & 1.734 & 2.99 \\
56.075 & 1.638 & 7.54 \\
59.200 & 1.56 & 8.30 \\
60.675 & 1.525 & 58.17 \\
52.222 & 1.491 & 13.16 \\
63.700 & 1.46 & 12.67 \\
65.198 & 1.43 & 4.85 \\
68.030 & 1.377 & 8.11 \\
69.475 & 1.351 & 5.16 \\
73.745 & 1.284 & 5.63 \\
75.102 & 1.264 & 8.50 \\
76.272 & 1.247 & 7.92
\end{tabular}
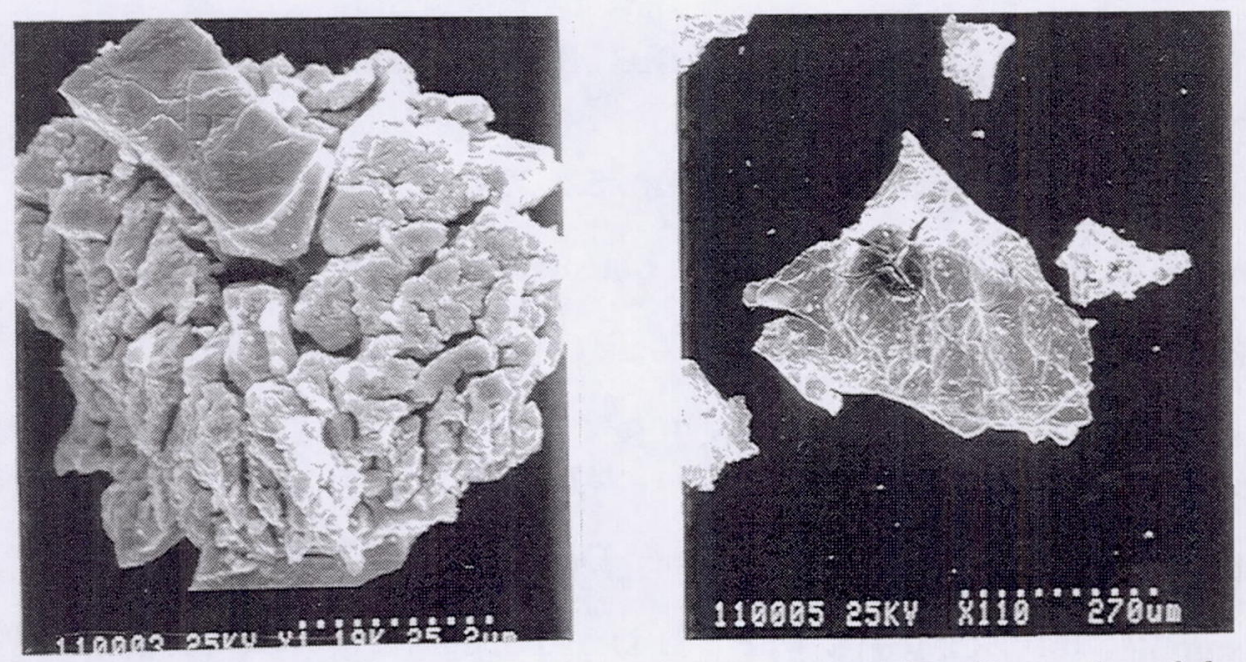

Figure 3. Scanning electron micrographs of typical samples of $\mathrm{In}_{2} \mathrm{O}_{3}$ produced during TGA experiments and charcterized by XRD, see text.

\section{CONCLUSIONS}

We have demonstrated a simple and direct one-step route to $\operatorname{In}\left(\eta^{2}-\mathrm{O}_{2} \mathrm{CC}_{6} \mathrm{H}_{5}\right)_{3}(4-\mathrm{Mepy})_{2}$, the first mononuclear eight-coordinate indium(III) benzoate. Our approach to the synthesis of indium(III) carboxylates differs significantly from previously reported methods [4-11]. The presence of 4-methylpyridine at the initial stages of reaction virtually eliminates all probability of In $\left(\mathrm{O}_{2} \mathrm{CR}\right)_{3}$ polymerization by coordinatively saturating the indium(III) center as it is formed. In addition, we have established that (I) is a stable inorganic precursor to indium oxide. 


\section{ACKNOWLEDGEMENT}

A.F.H. (Director's Discretionary Fund), M.T.A. (Postdoctoral Fellowship, National Research Council/NASA Lewis Research Center), S.A.D. (NASA Cooperative Agreement NCC3-162), D.G.H. (NASA Cooperative Agreement NCC3-318), and P.E.F (NASA Cooperative Agreement NCC3-246) acknowledge support from NASA Lewis Research Center. We thank Ms. Ruth Cipcic (XRD, NASA LeRC) and Mr. Frederick K. Oplinger (NMR, CSU) for assistance.

\section{REFERENCES}

1. I. Weinberg, Solar Cells 29, 225 (1990).

2. J. van de Ven, J.J.M. Binsma, and N.M.A. de WIld, J. Appl. Phys. 67, 7568 (1990).

3. M.T. Andras, S.A. Duraj, A.F. Hepp, P.E. Fanwick, and M.M. Bodnar, J. Am. Chem. Soc. 114, 786 (1992).

4. R.C. Mehrotra and R. Bohra, Metal Carboxylates; (Academic Press, London, 1983) pp. 121-129, 178-181.

5. D.G. Tuck, in Comprehensive Organometallic Chemistry; Vol. 1, edited by G. Wilkinson, F.G.A. Stone, E.W. Abel, (Pergamon Press, New York, 1982) pg. 719.

6. V.W. Lindel and F.Z. Huber, Anorg. Allg. Chem. 408, 167 (1974).

7. H.D. Hausen, J. Organometal. Chem. 39, C37 (1972).

8. F.W.B. Einstein, M.M. Gilbert, and D.G. Tuck, J. Chem. Soc., Dalton Trans., 248 (1973).

9. J.J. Habeeb and D.G. Tuck, Can. J. Chem. 52, 3950 (1974).

10. R. Nomura, S. Fujii, K. Kanaya, and H. Matsuda, Polyhedron 9, 361 (1990).

11. M.A. Khan, C. Peppe, and D.G. Tuck, Acta Cryst. C39, 1339 (1983).

12. M.T. Andras, A.F. Hepp, S.A. Duraj, E.B. Clark, D.A. Scheiman, D.G. Hehemann, and P.E. Fanwick, Inorg. Chem. 32, 4150 (1993).

13. J.J.Habeeb and D.G. Tuck, J. Chem. Soc., Dalton Trans., 243 (1973).

14. For example, $\mathrm{In}\left(\mathrm{O}_{2} \mathrm{CMe}\right)_{3} \mathrm{~L}$ where $\mathrm{L}$ is a bidentate $\mathrm{N}, \mathrm{N}^{\prime}$-donor molecule, i.e., 2,2' bipyridine or 1,10-phenanthroline; see V.H. Preut and F.Z. Huber, Anorg. Allg. Chem. 450, 120 (1979).

15. R. Kumar, H.E. Mabrouk, and D.G. Tuck, J. Chem. Soc., Dalton Trans., 1045 (1988).

16. The diffraction pattern was matched with $\mathrm{In}_{2} \mathrm{O}_{3}$ in the JCPDS International Center for Diffraction Data 1989. Powder Diffraction File No. 6-0416.

17. Chemical analysis showed total $\mathrm{C}, \mathrm{H}$, and $\mathrm{N}$ content below detection limit.

18. Handbook of Chemistry and Physics, edited by R.C. Weast, 55th ed. (Chemical Rubber Company Press, Cleveland, OH, 1974) pg. B-96. 
Public reporting burden for this collection of information is estimated to average 1 hour per response, including the time for reviewing instructions, searching existing data sources, gathering and maintaining the data needed, and completing and reviewing the collection of information. Send comments regarding this burden estimate or any other aspect of this collection of information, including suggestions for reducing this burden, to Washington Headquarters Services, Directorate for Information Operations and Reports, 1215 Jefle
Davis Highway, Suite 1204. Arlington, VA 22202-4302, and to the Office of Management and Budget, Paperwork Reduction Project (0704-0188), Washington, DC 20503.

\begin{tabular}{|l|l|l|}
\hline 1. AGENCY USE ONLY (Leave blank) & $\begin{array}{r}\text { 2. REPORT DATE } \\
\text { July } 1994\end{array}$ & $\begin{array}{r}\text { 3. REPORT TYPE AND DATES COVERED } \\
\text { Technical Memorandum }\end{array}$ \\
\hline
\end{tabular}

4. TITLE AND SUBTITLE 5. FUNDING NUMBERS

Synthesis and Decomposition of a Novel Carboxylate Precursor to Indium Oxide

6. AUTHOR(S)

WU-233-01-0A

Aloysius F. Hepp, Maria T. Andras, Stan A. Duraj, Eric B. Clark, David G. Hehemann, Daniel A. Scheiman, and Phillip E. Fanwick

7. PERFORMING ORGANIZATION NAME(S) AND ADDRESS(ES)

8. PERFORMING ORGANIZATION REPORT NUMBER

National Aeronautics and Space Administration

Lewis Research Center

E-8715

Cleveland, Ohio 44135-3191

9. SPONSORING/MONITORING AGENCY NAME(S) AND ADDRESS(ES)

10. SPONSORING/MONITORING AGENCY REPORT NUMBER

National Aeronautics and Space Administration

Washington, D.C. 20546-0001

NASA TM-106555

11. SUPPLEMENTARY NOTES

Prepared for the Fall Meeting sponsored by the Materials Research Society, Boston, Massachusetts, November 29-December 3, 1993. Aloysius F. Hepp and Eric B. Clark, NASA Lewis Research Center; Maria T. Andras, National Research Council-NASA Research Associate at Lewis Research Center; Stan A. Duraj, Department of Chemistry, Cleveland State University, Cleveland, Ohio 44115 (work funded by NASA Cooperative Agreement NCC3162); David G. Hehemann, School of Technology, Kent State University, Kent, Ohio 44242, and Senior Research Fellow-NASA Resident Research Associate at Lewis Research Center (work funded by NASA Cooperative Agreement NCC3-318); Daniel A. Scheiman, Sverdrup Technology, Inc., Lewis Research Center Group, 2001 Aerospace Parkway, Brook Park, Ohio 44142 (work funded by NASA Contract NAS3-25266); and Phillip E. Fanwick, Department of Chemistry, Purdue University, West Lafayette, Indiana 47907 (work funded by NASA Cooperative Agreement NCC3-246). Responsible person, Aloysius T. Hepp, organization code 5410, (216) 433-3835.

12a. DISTRIBUTION/AVAILABILITY STATEMENT 12b. DISTRIBUTION CODE

Unclassified - Unlimited

Subject Category 23

\section{ABSTRACT (Maximum 200 words)}

Reaction of metallic indium with benzoyl peroxide in 4-methylpyridine (4-Mepy) at $25^{\circ} \mathrm{C}$ produces an eight-coordinate mononuclear indium(III) benzoate, In $\left(\eta^{2}-\mathrm{O}_{2} \mathrm{CC}_{6} \mathrm{H}_{5}\right)_{3}(4-\mathrm{Mepy})_{2} \bullet 4 \mathrm{H}_{2} \mathrm{O}$ (I), in yields of up to $60 \%$. The indium(III) benzoate was fully characterized by elemental analysis, spectroscopy, and X-ray crystallography; (I) exists in the crystalline state as discrete eight-coordinate molecules; the coordination sphere around the central indium atom is best described as pseudo-square pyramidal. Thermogravimetric analysis of (I) and X-ray diffraction powder studies on the resulting pyrolysate demonstrate that this new benzoate is an inorganic precursor to indium oxide. Decomposition of (I) occurs first by loss of 4 -methylpyridine ligands $\left(100^{\circ}-200^{\circ} \mathrm{C}\right)$, then loss of benzoates with formation of $\operatorname{In}_{2} \mathrm{O}_{3}$ at $450^{\circ} \mathrm{C}$. We discuss both use of carboxylates as precursors and our approach to their preparation.

\begin{tabular}{|c|c|}
\hline \multicolumn{2}{|l|}{ 14. SUBJECT TERMS } \\
\hline $\begin{array}{l}\text { 17. SECURITY CLASSIFICATION } \\
\text { OF REPORT } \\
\text { Unclassified }\end{array}$ & $\begin{array}{l}\text { 18. SECURITY CLASSIFICATION } \\
\text { OF THIS PAGE } \\
\text { Unclassified }\end{array}$ \\
\hline
\end{tabular}

\begin{tabular}{|c|c|}
\hline & $\begin{array}{l}\text { 15. NUMBER OF PAGES } \\
8\end{array}$ \\
\hline & $\begin{array}{r}\text { 16. PRICE CODE } \\
\text { A02 }\end{array}$ \\
\hline $\begin{array}{l}\text { 19. SECURITY CLASSIFICATION } \\
\text { OF ABSTRACT } \\
\text { Unclassified }\end{array}$ & 20. LIMITATION OF ABSTRACT \\
\hline
\end{tabular}

